\title{
Indirect Genotoxic Effect of Gamma Rays in Human Peripheral Lymphocytes
}

\author{
Ahmet Kayraldız ${ }^{1}$ and Mehmet Topaktaş ${ }^{2}$ \\ ${ }^{1}$ Çukurova University, Institute of Natural and Applied Science, 01330-Adana-Turkey \\ ${ }^{2}$ Çukurova University, Faculty of Arts and Sciences, Department of Biology, 01330-Adana-Turkey
}

Accepted October 26, 2000

\begin{abstract}
Summary The aim of this study was to investigate the indirect genotoxic effect of various doses of gamma rays in human peripheral lymphocytes. For this aim, chromosome mediums were irradiated with various doses $(2000,4000,8000,16000 \mathrm{rad})$ of gamma rays.

In this study, we were found that SCE (Sister Chromatid Exchange) was increased by gamma rays doses-dependently. In addition to these, percentages of abnormal cells with chromosomal abnormalities and CA (Chromosome Aberration)/Cell were increased by all doses of gamma rays compared to control. Besides, gamma rays decreased the MI dose-dependently. RI was not also reduced at all concentrations.
\end{abstract}

Key words Human peripheral lymphocytes, Gamma ray, Indirect genotoxic effect, SCE, CA.

Problem of nourising appeared together with increasing the population of the world. In the last 30 years, the sector of the storing the food products for a long time and increasing the food quality have became very important developments. The most important development of this sector is also irradiation technology. According to the experiments were made by researcher, ionising gamma rays have increased the endurance time of the foods, have decreased the number of the microorganizms of the foods, have destroyed the patojen microorganizms and parasites and also have impeded to be sprouted and to be vermin in herbal foods.

Firstly, X ray was used to against Trichinella spiralis by Scwartz (Scwartz 1921 from Uğur 1977). Mc Alister et al. (1991) found that gamma ray and ethylen oxide destroyed the natural microorganism populations that localized over the white and maize seeds. On the other hand, this method caused to change of the seed structure.

Hiemstra et al. (1991) observed that gamma radiation must be disregarded as a method for the sterilisation of plasma and plasma derived products, because of the fact that gamma rays didn't reduce the HIV virus activity.

The effective ingredients of chemical substance (Matteucci et al. 1993), the broths (Kornhof et al. 1994) and the solid poly polimers (ortho ester) that contaminated with Bacillus bacterium (Merkli et al. 1994) were sterilized by gamma rays but it was found that structure of these substances were damaged.

Shintani (1995) reported that methylenediailine that is a carcinogen was dose-dependent formed after gamma irradiation of poliürethan. Ten kinds of spice were sterilized with gamma rays at different doses (6, 12, $25 \mathrm{kGy}$ ) (Uğur 1997).

Although gamma rays were used to various sectors in order to sterilization, gamma rays caused to spoil and breakage of structure of substances that irradiated with high doses.

Mäder et al. (1996) investigated whether gamma rays caused to forming the free radicals after irradiated the polimers that used in medicine and was reported that the temperature of irradiation affect a little bit the forming of free radicals. However it was found that, the polymerase that was high melting temperature and cristallization was occured max level of free radicals in room temperature after irradiation (Mäder et al. 1996). 
It was founded that gamma and $\mathrm{X}$ rays directly induced chromosomal aberrations in human lymphocytes (Guedeney et al. 1988, Lefrançois et al. 1989, Lijima and Morimoto 1991, MilkoviçKraus et al. 1992, Chambrette et al. 1996), in human fibroblast cells (Mühlmann-Diaz and Bedford 1995), in monkey lymphocytes (Guedeney et al. 1988, 1989, Van Buul 1983), in mouse spermatocytes (Van Buul et al. 1996) and in polen mother cells of Capsicum annuum (Rao and Lakshmi 1980) and especially they increased heterozigot resiprokal translocation in barley polen mother cells (Bilge et al. 1984). In addition, these rays also induced formation of micronuclei (Countryman and Heddle 1976, Huber et al. 1992, Köksal et al. 1996).

It was known that gamma rays caused to form free radicals in substances which irradiated sterilized. Foods and polymers which are used as a drug in medical treatment have been irradiated sterilized by gamma rays. As mentioned above, gamma rays have also directly damaged in genetic structure. For this reason, the aim of this study was to investigate whether induced the SCE and the $\mathrm{CA}$ in human peripheral lymphocytes incubated in Chromosome Medium B which is irradiated with various doses of gamma rays.

\section{Material and methods}

The $2.5 \mathrm{ml}$ Chromosome Medium B (Biocrom F 5023) in steril tube were irradiated with 2000, 4000,8000 and $16000 \mathrm{rad}$ gamma rays $\left({ }^{60} \mathrm{Co}\right.$, Alcyon, $\left.200 \mathrm{rad} / \mathrm{min}\right)$ within $30 \mathrm{~min}$ irradiation whole blood $(0.2 \mathrm{ml})$ from 2 male and 1 female (age 23, 24, 26; non smokers) were added to $2.5 \mathrm{ml}$ Chromosome Medium B irradiated with gamma rays. After this procedure, Bromodeoxyuridine (BrdUrd) (Sigma) $(10 \mu \mathrm{g} / \mathrm{ml})$ was added to medium and the cultures were incubated at $37^{\circ} \mathrm{C}$ for $72 \mathrm{~h}$. And then Colchicine $(0.06 \mu \mathrm{g} / \mathrm{ml}$ final concentration) was added for the last $2 \mathrm{~h}$ of culture. To collect cells, the cultures were centrifuged $(1200 \mathrm{rpm}, 15 \mathrm{~min})$, treated with hypotonic solution $(0.4 \% \mathrm{KCI})$ for $33 \mathrm{~min}$ at $37^{\circ} \mathrm{C}$, and then fixed in cold fixative (methanol: glacial acetic acid $3: 1$ ) for $20 \mathrm{~min}$ at room temperature. The treatment with fixative was repeated 3 times. The cells were spread on glass slides and air dried. The slides were stained by modified fluorescence plus Giemsa technique according the method of Speit and Haupter (1985) and mounted with entellan.

The significance between mean SCE, RI, MI and their controls were determined using the $t$ test. The significance between percentage of abnormal cell, $\mathrm{CA} /$ cell and their controls were determined using the $\chi^{2}$-test. Dose response relationship were determined from the corelation and regression coefficients and the corresponding regression lines.

\section{Results}

In this study, gamma rays indirectly induced the SCE. However, the mean of the SCE in human lymphocytes that incubated in medium irradiated with 16000 rad gamma rays were only increased compared to the control (Table 1). In addition gamma rays indirectly induced SCE dose-dependently (Fig. 1).

Table 1. The SCE, RI and MI in human lymphocytes that incubated in irradiated medium

\begin{tabular}{cccccccc}
\hline \hline Dosage (rad) & Min-Max SCE & SCE/Cell \pm SE & M1 & M2 & M3 & RI \pm SE & MI \pm SE \\
\hline Control & $1-12$ & $4.47 \pm 0.27$ & 89 & 142 & 69 & $1.93 \pm 0.06$ & $1.93 \pm 0.18$ \\
2000 & $2-13$ & $4.99 \pm 0.22$ & 98 & 135 & 67 & $1.89 \pm 0.07$ & $1.36 \pm 0.12^{*}$ \\
4000 & $1-14$ & $4.86 \pm 0.29$ & 120 & 140 & 40 & $1.73 \pm 0.12$ & $1.46 \pm 0.22$ \\
8000 & $1-16$ & $5.16 \pm 0.43$ & 134 & 125 & 41 & $1.49 \pm 0.21$ & $1.06 \pm 0.19^{*}$ \\
16000 & $2-13$ & $5.46 \pm 0.20^{*}$ & 129 & 136 & 35 & $1.68 \pm 0.05$ & $0.56 \pm 0.15^{* *}$ \\
\hline
\end{tabular}

*: $\mathrm{P}<0.05, * *: \mathrm{P}<0.02$ 
At all doses, percentages of abnormal cells were significantly increased in human peripheral lymphocytes that incubated in irradiated medium compared to the control (Table 2). This increase was shown at a maximum rate in lymphocytes that incubated in medium that was irradiated by gamma rays at 4000 and $8000 \mathrm{rad}$.

The CA/cell was significantly increased compared to the control (Table 2). The maximum $\mathrm{CA} /$ cell was shown at 4000 and $8000 \mathrm{rad}$.

Gamma rays indirectly caused to various chromosomal aberrations like as sister union (Fig. 2), chromatid brekage (Fig. 3), chromatid exchange (Fig. 4). In addition gamma rays also caused to formed of gaps.

In this experiment, gamma rays indirectly decreased the MI compared to the control (Table 1). In addition this decreasing was dose-dependent (Fig. 5). However, gamma rays didn't also reduce the RI (Table 1).

\section{Discussion}

\section{Indirectly induction of the SCE by gamma rays}

In this study, gamma rays generally induced the SCE in human peripheral lymphocytes indirectly. But this increasing was found statistically significant compared to the control only at the cultures irradiated with 16000 rad gamma rays. In addition, gamma rays also increased the SCE dosedependently.

It was found that the SCE was directly increased by irradiation after adding BrdUrd in mouse bone marrow cells (Morales-Ramirez et al. 1984). In addition it was reported that gamma rays directly increased the SCE in Bloom syndrome person who already have high level of the SCE (Aurias et al. 1985). It has been reported that $0.5 \mathrm{~Gy}$ gamma rays directly increased the SCE in CHO xrs-6c and K-1c cell lines irradiated at $\mathrm{G}_{0}$ phase (Nagasawa et al. 1991). Moreover, it was reported that chlorophyllin prevented the SCE that were induced by gamma rays in murine bone marrow cells (Morales-Ramirez and Garcia-Rodriguez 1994). On the other hand, gamma rays didn't induce the SCE in human lymphocytes that irradiated with gamma rays at $\mathrm{G}_{0}$ phase directly (Lijima and Morimoto 1991). In addition, Mühlmann-Diaz and Bedford (1995) also showed that both gamma rays and X rays didn't induce the SCE in human fibroblast which were irradiated with

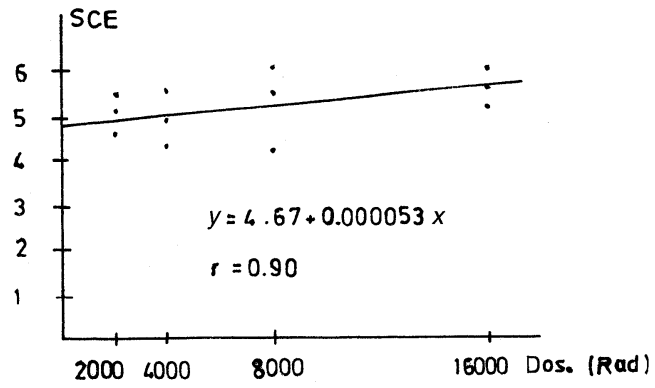

Fig. 1. Correlation coefficient and regression lines of SCE in human lymphocytes that incubated in irradiated medium.

Table 2. The chromosomal abnormalities and gap, the percentage of abnormal cells and the CA/cell in human peripheral lymphocytes that incubated in irradiated medium

\begin{tabular}{|c|c|c|c|c|c|c|c|c|c|}
\hline \multirow{2}{*}{ Dosage (rad) } & \multicolumn{7}{|c|}{ Chromosomal Aberration and Gap ${ }^{*}$} & \multirow{2}{*}{ Abnormal cell (\%) } & \multirow{2}{*}{ CA/Cell } \\
\hline & $\mathrm{B}^{\prime}$ & SU & DS & $\mathrm{T}$ & $\mathrm{CE}$ & $\mathrm{P}$ & G & & \\
\hline Control & 1 & - & - & - & - & - & 1 & $0.333 \pm 0.333$ & $0.003 \pm 0.003$ \\
\hline 2000 & - & 8 & 1 & - & - & - & 2 & $3.000 \pm 1.155^{* * *}$ & $0.037 \pm 0.015 * * * *$ \\
\hline 4000 & 3 & 12 & - & - & - & 1 & 6 & $5.333 \pm 1.667 * * * *$ & $0.057 \pm 0.019^{* * * *}$ \\
\hline 8000 & - & 12 & 1 & - & 1 & - & - & $4.667 \pm 1.333 * * * *$ & $0.050 \pm 0.015^{* * * *}$ \\
\hline 16000 & - & 8 & - & 1 & - & - & 2 & $3.000 \pm 0.577 * * * *$ & $0.037 \pm 0.009 * * * *$ \\
\hline
\end{tabular}

B': Chromatid Brekage, SU: Sister Union, DS: Disentric Chromosome, T: Translocation, CE: Chromatid Exchange, P: Poliploid Cell, G: Gap. *: $\mathrm{P}<0.05$, **: $\mathrm{P}<0.02, * * *: \mathrm{P}<0.01, * * * *: \mathrm{P}<0.001$. 

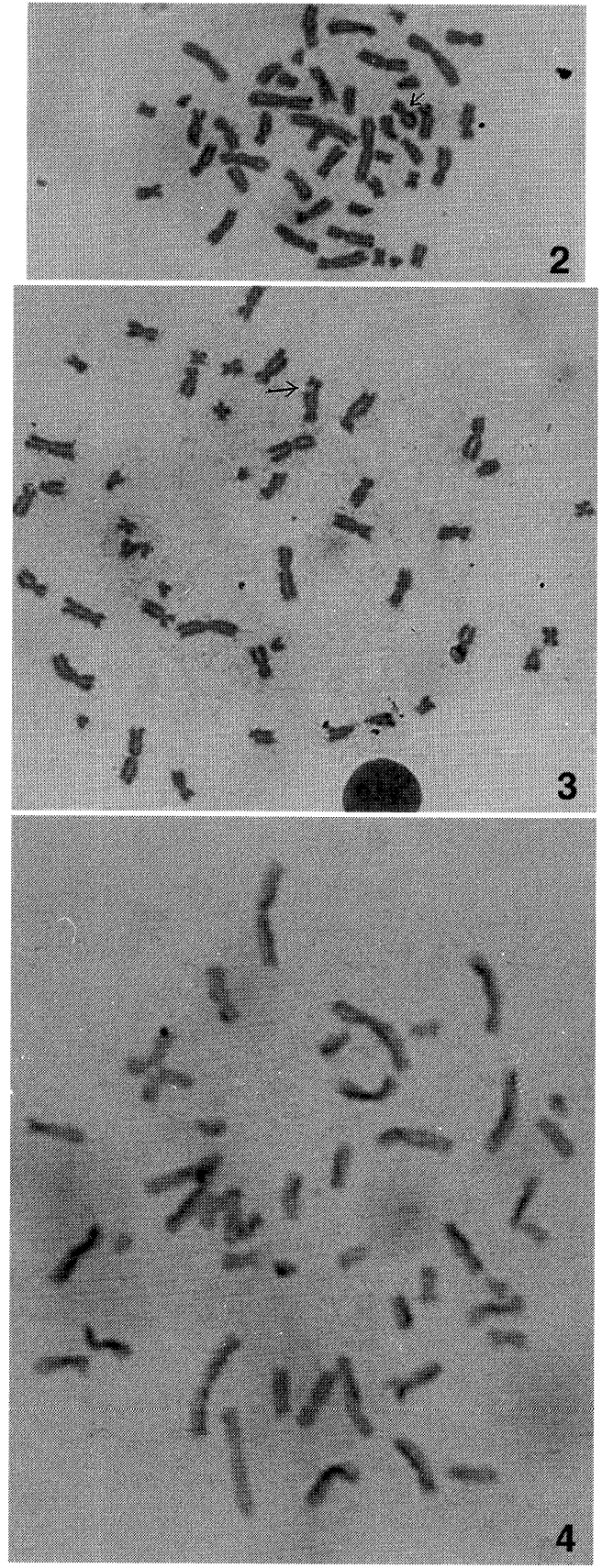

Figs. 2-4. 2) Sister union (8000 rad gamma ray, ९). 3) Chromatid brekage (4000 rad gamma ray, $\left.{ }^{\star}\right)$. 4) Chromatid exchange (8000 rad gamma ray, $\delta^{\star}$ ).

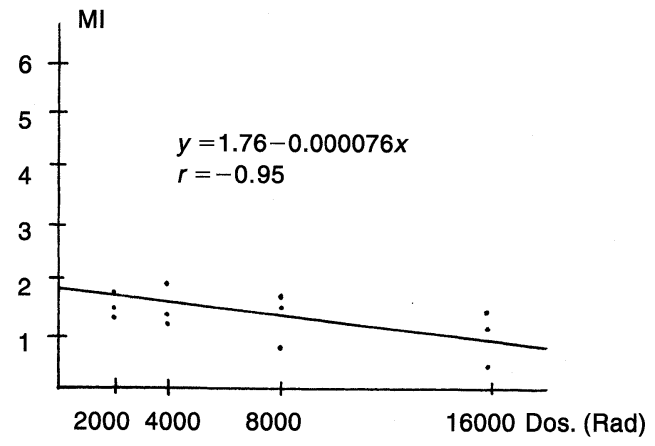

Fig. 5. Correlation coefficient and regression lines of the MI in human lymphocytes that incubated irradiated medium.

$1.5,2.5,4.5$ and 7 Gy of gamma rays and $X$ rays at $G_{0}$ and $G_{1}$ phase directly. As understood from our and other researcher results, SCE was induced directly and indirectly in some cell lines that gamma rays irradiated while in some cell lines the SCE weren't induced after irradiated with gamma rays. It was understood that the cell lines is very important for the investigating the genotoxic effects of rays using the SCE test system. In addition, feeding the cells also affected the SCE formation. On the other hand, cysteamin and chlorophyllin are radical scavenger properties. Reason of SCE which could not be increased in some cell lines may be arised from the higher level of scavenger molecules (Özalpan 1980, Morales-Ramirez and Garcia Rodriguez 1994). As mentioned above, some researchers indicated that gamma rays were directly induced the SCE. Some researchers found that gamma rays didn't induce the SCE directly. On the other hand, Mendiola-Cruz and Morales-Ramirez (1989) also found that free radicals didn't induce the SCE. Whereas, we found that gamma rays indirectly induced the SCE in human peripheral lymphocytes. The difference between our and these researchers' results proceed from using different cell lines and irradiation doses.

\section{Indirectly induction of the CA by gamma rays}

In this study, gamma rays indirectly induced the CA at all doses. Chromatid breaks and sister unions were the most common abnormalities observed. Gamma rays directly induced the CA in human lymphocytes (Brandriff et al. 1988, Lefrançois et al. 1989, Lijima and Morimoto 1991, Milkoviç-Kraus et al. 1992, Huber et al. 1992, Kosaka et al. 1995, Sing et al. 1995, Köksal et al. 
1996, Chambrette et al. 1996, Garcia-Sagredo et al. 1996), in human chorionic villi (Salvi et al. 1993), in Macaca mulatta lymphocytes (Guedeney et al. 1988), in cynomolgus peripheral lymphocytes (Guedeney et al. 1989), in rhesus monkey (Van Buul 1989) and in mouse (Sjoblom et al. 1995, Zang 1995). It is shown that gamma rays directly and indicrectly affected the DNA and caused to chromosome mutation.

In this study, it was not observed that any dose-response relationship. Because the CA at $16000 \mathrm{rad}$ is less than 4000 and $8000 \mathrm{rad}$. This situation may be caused from eliminating of abnormal cells at 16000 rad. In this study, SU has been observed as the most abnormality due to the terminal deletion. Sasaki and Matsubara (1977) reported that the chromatid exchange which was caused from free radicals wasn't repaired while the terminal deletion was repaired. In this study, it was shown that the terminal deletion was not repaired because of forming of the SU as the most common abnormality. In addition the doses that used in this study (2000, 4000, 8000, $16000 \mathrm{rad})$ were rather higher than the doses that used by Sasaki and Matsubara (1977) (300 rad).

\section{Indirectly cytotoxic effect of gamma rays}

In this study, MI was decreased dose-dependently but RI was not affected. For this reason, it was understood that the gamma rays decreased the MI via the affecting of $\mathrm{G}_{2}$ and prophase. However, the decreasing of the MI might be caused by the decreasing of the ATP level and the pressure from the functioning of the energy producting centre (Epel 1963, Jain and Andsorbhoy 1988).

As a result, free radicals have formed in chromosome medium which was irradiated by gamma rays and it was also known that free radicals have genotoxic effect. We are opinion that free radicals should be measured in food that sterilized by irradiation and should be also determined the time-dependently decreasing of the quantitive of the free radicals.

\section{Acknowledgements}

This study was supported by Ç.U. Research Fund, 99.YL.2.

\section{References}

Aurias, A., Antonie, J. L., Assathiany, R., Odievre, M. and Dutrillaux, B. 1985. Radiation sensitivity of Bloom's Syndrome lymphocytes during $S$ and $\mathrm{G}_{2}$ phases. Cancer. Genet. Cytogenet. 16: 131-136.

Bilge, E., Topaktaş, M. and Kaymak, F. 1984. Arpada X ve gamma işinlarina tutulmuş polenlerde yapay melezleme sonucu elde edilen $F_{1}$ dölünde sitogenetik incelemeler. Doğa Bilim Dergisi 8: 13-19.

Brandriff, B. F., Gordon, L. A., Ashworth, L. K. and Carrano, A. V. 1988. Chromosomal aberrations induced by in vitro irradiation: Comparisons between human sperm and lymphocytes. Environ. Mol. Mutagen. 12: 167-177.

Chambrette, V., Laroche, P., Lataillade, J. J. and Voisin, P. 1996. Effect of cryopreservation on chromosomal aberration yield in irradiated lymphocytes. Int. J. Radiat. Biol. 70: 671-675.

Countryman, P. I. and Heddle, J. A. 1976. The production of micronuclei from chromosome aberrations in irradiated cultures of human lymphocytes. Mut. Res. 41: 321-332.

Epel, D. 1963. The effects of carbonmonoxide inhibition of ATP level and the date of mitosis in sea urching egg. J. Cell. Biol. 17: 315-319.

Garcia-Sagredo, J. M., Vallcorba, I., Lopez-Yarto, A., Sanchez-Hombre, M. D. C., Resino, M. and Ferro, M. T. 1996. Chromosome painting in biological dosimetry. Assessment of the ability to score stabla chromosome aberrations using different pairs of paintprobes. Environmental Health Perspectives. 10: 475-477.

Guedeney, G., Grünwald, D., Malarbet, J. L. and Doloy, M. T. 1988. Time dependence of chromosomal aberrations induced in human and monkey lymphocytes by acute and fractionated to ${ }^{60} \mathrm{Co}$. Radiat. Res. 166: $245-262$.

-, Malarbet, J. L. and Doloy, M. T. 1989. Chromosomal aberration in Cynomolgus peripheral lymphocytes during and after fractionated wholebody gamma irradiation. Int. J. Radiat. Biol. 55: 861-870.

Hiemstra, H., Tersmette, M., Vos, A. H. V., Over, J., Van Berkel, M. P. and De Bree, H. 1991. Inactivation of human immunodeficiency virus by gamma radiation and its effect of plazma and coagulation factor. Transfüsion. 31: 32-39.

Huber, R., Braselmann, H. and Bauchinger, M. 1992. Intra- and inter-individual variation of background and radiation-in- 
duced micronucleus frequencies in human lymphoctes. Int. J. Radiat. Biol. 61: 655-661.

Jain, A. and Andsorbhoy, R. K. 1988. Cytogenetical studies on the effects of some chlorinated pesticites III. Concluding remarks. Cytologia 53: 427-436.

Köksal, G., Dalci, Ö. and Pala, F. S. 1996. Micronuclei in human lymphoctes: The Co-60 Gamma-ray dose-response. Mut. Res. 359: 151-157.

Kornhof, H. J., Isacson, M., Saunders, J., Van Why, C. J., Kotze, A. F., Rosekilly, A. and Du Plessis, T. A. 1994. Enhancement of microbiological safety levels of aseptically admixed total parenteral nutrition solutions through low-dose gamma irradiation. J. Clinic. Pharm. Therap. 19: 249-256.

Kosaka, T., Tsukahara, M., Kaneko, I., Nakano, K., Tanaka, S. and Koide, F. 1995. Alteration of gamma-ray-induced chromosome aberration by $0.5 \mathrm{M} \mathrm{NaCI}$ in Chinese hamster cells. Int. J. Radiat. Biol. 67: 687-691.

Lefrançois, D., Alalchkar, W., Aurias, A., Couturier, J., Dutrillaux, A. M., Dutrillaux, B., Flury-Herard, A., GerbaultSeureau, M., Hoffschir, F., Lamoliate, E., Lombard, M., Muleris, M., Prieur, M., Ricoul, M., Sabattier, L. and Viegas-Pequignot, E. 1989. Chromosomal aberrations induced low-dose gamma irradiation. Study of R-banded chromosomes of human lymphocytes. Mut. Res. 212: 167-172.

Lijima, K. and Morimoto, K. 1991. Quantitative analyses of the induction of chromosome aberrations and sister-chromatid exchange in human lymphocytes exposed to gamma rays and mitomycin C in combination. Mut. Res. 263 263-268.

Mäder, K., Domb, A. and Swartz, H. M. 1996. Gamma-sterilization-induced radicals in biodegradable drug delivery system. Appl. Radiat. Isot. 47: 1669-1674.

Matteucci, P., Celletti, P., Picelle, G., Lencioni, E. and Franchi, G. 1993. Time stability of a drug molecule sterilized through gamma rays. Boll. Chim. Farmaceutio-Anno. 132: 120-125.

Mc Alister, T. A., Rode, L. M., Cheng, K. J. and Forsberg, G. W. 1991. Selection of a sterilization method for the study of cereal grain digestion. J. Anim. Sci. 69: 3039-3043.

Mendiola-Cruz, M. T. and Morales-Ramirez, P. 1989. Effect of pretreatment with cysteamine on gamma-radiation-induced sister chromatid exchanges in mouse bone marrow cells in vivo. Radiat. Res. 118: 131-138.

Merkli, A., Heller, J., Tabatabay, C. and Guny, R. 1994. Gamma sterilization of a semi-solid poly (ortho ester) designed for controlled drug delivery-validation and radiation effects. Pharmaceutical Res. 11: 1485-1491.

Milkoviç-Kraus, S., Kubelka, D. and Vekic, B. 1992. Biological monitoring of three ${ }^{60}$ Co radiation incident. Amer. J. of Industrial Med. 22: 243-247.

Morales-Ramirez, P. and Garcia-Rodriguez, M. C. 1994. In vivo effect of chlorophyllin on gamma ray-induced sister chromatid exchange in murine bone marrow cells. Mut. Res. 320: 329-334.

-, Vallarino-Kelley, T. and Rodriguez-Reyes, R. 1984. In vivo persistence of sister chromatid exchanges by gamma rays in mouse bone marrow cells. Environ. Mutagen. 6: 529-537.

Mühlmann-Diaz, M. C. and Bedford, J. S. 1995. Comparison of gamma-ray-induced chromosome ring and inversion frequencies. Radiat. Res. 143: 175-180.

Nagasawa, H., Little, J. B., Indret, W. C., Carpenter, S., Raju, M. R., Chen, D. J. and Strniste, G. F. 1991. Response of X-raysensitive $\mathrm{CHO}$ mutant cells (xrs-6c) to radiation. II. Relationship between alpha particles. Radiat. Res. 126: $280-288$.

Özalpan, A. 1980. Istanbul Üniversitesi Fen Fakültesi Basmevi. Istanbul. 222s.

Rao, N. B. and Lakshmi, N. 1980. Gamma ray induced meiotic abnormalities in Capsicum annuum L. Cytologia 33 509-518.

Salvi, R., De Andreas, C., Pariani, S., Piantanida, M., Rosella, F. and Simoni, G. 1993. Frequency of chromosomal aberrations after exposure to gamma-radiation of human chorionic villi. Mut. Res. 291: 213-216.

Sasaki, M. S. and Matsubara, S. 1977. Free radicals scavenging in protection of human lymphocytes againts chromosome aberration formation by gamma-ray radiation. Int. J. Radiat. Biol. Relat. Stud. Phys. Chem. Med. 32: 439-445.

Shintani, H. 1995. Formation and elution of toxic compounds from sterilized medical products. Methylenedianiline formation in polyurethane. J. Biomater. Appl. 10: 23-58.

Sing, N. P., Graham, M. M., Sing, V. and Khan, A. 1995. Induction of DNA singlestrand breaks in human lymphocytes by low doses gamma rays. Int. J. Radiat. Biol. 68: 563-569.

Sjoblom, T., Parvinen, M. and Lahdetie, J. 1995. Stage-spesific DNA synthesis of rat spermatogenesis as an indicator of genotoxic effect of Vinblastine, Mitomycin $\mathrm{C}$ and ionizing radiation on rat spermatogonia and spermatocytes. Mut. Res. 331: 181-190.

Speit, G. and Haupter, S. 1985. On the mechanism of differential giemsa staining of Bromodeoxyuridine substituted cromosomes. II. Differences between the demonstration of sister chromatid differentiation and replication patterns. Hum. Gen. 70: 126-129.

Uğur, F. A. 1997. Işinlama yöntemi ile glda ürünlerinin korunmasi ve kalite arttirimi. Ç.Ü. Fen Bilimleri Enstitüsü, Fizik Anabilim Dali, Yüksek Lisans Tezi. 66s.

Van Buul, P. P. W. 1983. X-ray-induced resiprocal translocation in stem-cell spermatogonia of the rhesus monkey: Dose and 
fractioned responses. Mut. Res. 107: 337-345.

- 1989. The induction by ionizing radiation of chromosomal aberrations in rhesus monkey pre-meiotic germ: Effects of dose rate and radiation quality. Mut. Res. 225: 83-89.

—, Zandman, I. M., Natarajan, A. T. and Boei, J. J. A. 1996. Non-random chromosomal involvement in radiation-induced translocations in mouse spermatogonial stem cells. Mutagenesis 11: 391-393.

Zhang, L. 1995. Cytogenetic adaptive response induced by pre-exposure in human lymphocytes and bone marrow cells of mice. Mut. Res. 334: 33-37. 